\title{
Assessment of Soil Erosive Fragility Using Cross Mapping with Support of the Geographic Information System in the Municipality of São Francisco de Assis/RS/Brazil
}

\section{Avaliação da Fragilidade Erosiva Usando Cruzamento de Mapas com Apoio do Sistema de Informação Geográfica do Município de São Francisco de Assis/RS/Brasil}

\author{
Mariana Xavier de Oliveira ${ }^{1 *} \varangle$ (iD), Romario Trentin ${ }^{2} \varangle$ (iD), Luis Eduardo de Souza Robaina ${ }^{2} \varangle$ (iD) \\ ${ }^{1}$ Núcleo de ensino e conteúdo, Instituto Phytus - Santa Maria, Rio Grande do Sul, Brasil. \\ ${ }^{2}$ Departamento de Geociências, Universidade Federal de Santa Maria - Santa Maria, Rio \\ Recebido (Received): 24/04/2019 \\ Grande do Sul, Brasil. \\ E-mails: romario.trentin@gmail.com (RT); lesrobaina@yahoo.com.br (LESR). \\ *E-mail para correspondência: mxavieroliveira@gmail.com (MXO).
}

\begin{abstract}
The present study analyzes factors that condition the occurrence of erosive incisions in the municipality of São Francisco de Assis, located in the western region of Rio Grande do Sul, in the Ibicuí river basin. Multicriteria analysis with GIS support was used for the development of map algebra operations. The base maps for the definition of the map of erosive fragility were slope, soils, lithology and land use, with weights assigned to each of the variables present in the base maps. The mapping of erosive fragility was carried out by the map algebra operation carried out in the GIS, using the Raster Calculator tool. The areas with the lowest erosive fragility, occur in the NW portion of the municipality, and are related to the occurrence of natural tree vegetation. In the municipality, areas with medium erosive fragility occur at the extreme NE-E and NW, formed by soils on volcanic rocks or sandstone with volcanic contribution where the predominant uses agricultural. The occurrence of very high erosive fragility is associated with the substrate of sandstones, friable soils and low soil cover. The work showed the importance of the multicriteria relationship involving physical attributes of the landscape and the study of land use is essential in studies of fragility and environmental potential.
\end{abstract}

Keywords: Multicriteria Analysis; Erosive Fragility; Linear Erosion; São Francisco de Assis.

Resumo:O presente trabalho analisa fatores que condicionam a ocorrência de incisões erosivas no município de São Francisco de Assis, localizado na região oeste do Rio Grande do Sul, na bacia do rio Ibicuí. Utilizouse análise multicritério com apoio de SIG, para o desenvolvimento de operações de álgebra de mapas. Os mapas bases para a definição da fragilidade erosiva foram: declividade, solos, litologia e uso da terra, com pesos atribuídos a cada uma das variáveis presentes nos mapas bases. O mapeamento da fragilidade erosiva foi realizado pela operação de álgebra do mapa realizada no SIG, utilizando a ferramenta Raster Calculator. As áreas com menor fragilidade erosiva ocorrem na porção NW do município e estão relacionadas à ocorrência de vegetação arbórea natural. No município, áreas com fragilidade erosiva média ocorrem no extremo NE-E e NW, formadas por solos sobre rochas vulcânicas ou arenito com contribuição vulcânica onde predominam os usos agrícolas. A ocorrência de fragilidade erosiva muito alta está associada ao substrato de arenitos, solos friáveis e baixa cobertura do solo. O trabalho mostrou a importância da relação multicritério envolvendo atributos físicos da paisagem e o estudo do uso da terra sendo essencial em estudos de fragilidade e potencial ambiental.

Palavras-chaves: Análise Multicritério; Fragilidade Erosiva; Erosão Linear; São Francisco de Assis. 


\section{Introduction}

Landforms, lithologies and soils are the physical substratum on which human activities are developed and, therefore, zoning work that determines homogeneous units is fundamental for understanding geomorphological processes and how human actions can interfere with the environment.

Erosion incisions and other erosive processes are important for the characterization of the present conditions and represent a moment of the historical evolution of the degradation of the area (BIGARELLA et al., 1996).

Different authors have developed studies evaluating erosive susceptibility. The work of Domingues et al. (1998) with characterization and mapping of erosions indicating four groups of areas, distinguished by the different types of erosive processes; Bacellar (2000) determined that although the intense anthropic activity in the region, the gullies only develop in geologically and geomorphologically favorable locations; Valladares et al. (2012) developed a map of susceptibility to erosion by means of an additive multi-criteria model, with landforms information, pedology, use and coverage of land; Calderano Filho et al. (2014) evaluated the soil susceptibility to erosion based on parameters of soil types, vegetation cover, lithology, relief, precipitation and land use, allied to the thematic overlap in GIS, with attribution of specific values to each one of them, according to the degree of importance of these factors in relation to erosion; and Silva \& Oliveira (2015) made an analysis of susceptibility and potential to laminar erosion through cross-land use data, slope relief and soil types.

Other studies that discuss erosive processes, in the western region of Rio Grande do Sul, were developed by Fujimoto et al. (2010); Vieira \& Verdum (2015) and Caneppele, (2017).

The purpose of this study was through multi-criteria analysis and GIS support, establish a zoning of susceptibility to erosion in the area of São Francisco de Assis, carried out by the map algebra operation.

The municipality of São Francisco de Assis (Figure 1) is located in the western portion of Rio Grande do Sul, $485 \mathrm{~km}$ from the Porto Alegre and $142 \mathrm{~km}$ of Santa Maria. The area of the municipality is 2,508,45 $\mathrm{km}^{2}$, geographically limited by the coordinates $54^{\circ} 47$ '02 "at $55^{\circ} 53^{\prime} 54^{\prime \prime} \mathrm{W}$ and $29^{\circ} 10$ '03 "at $29^{\circ} 43^{\prime} 05^{\prime \prime} \mathrm{S}$ (IBGE, 2018).

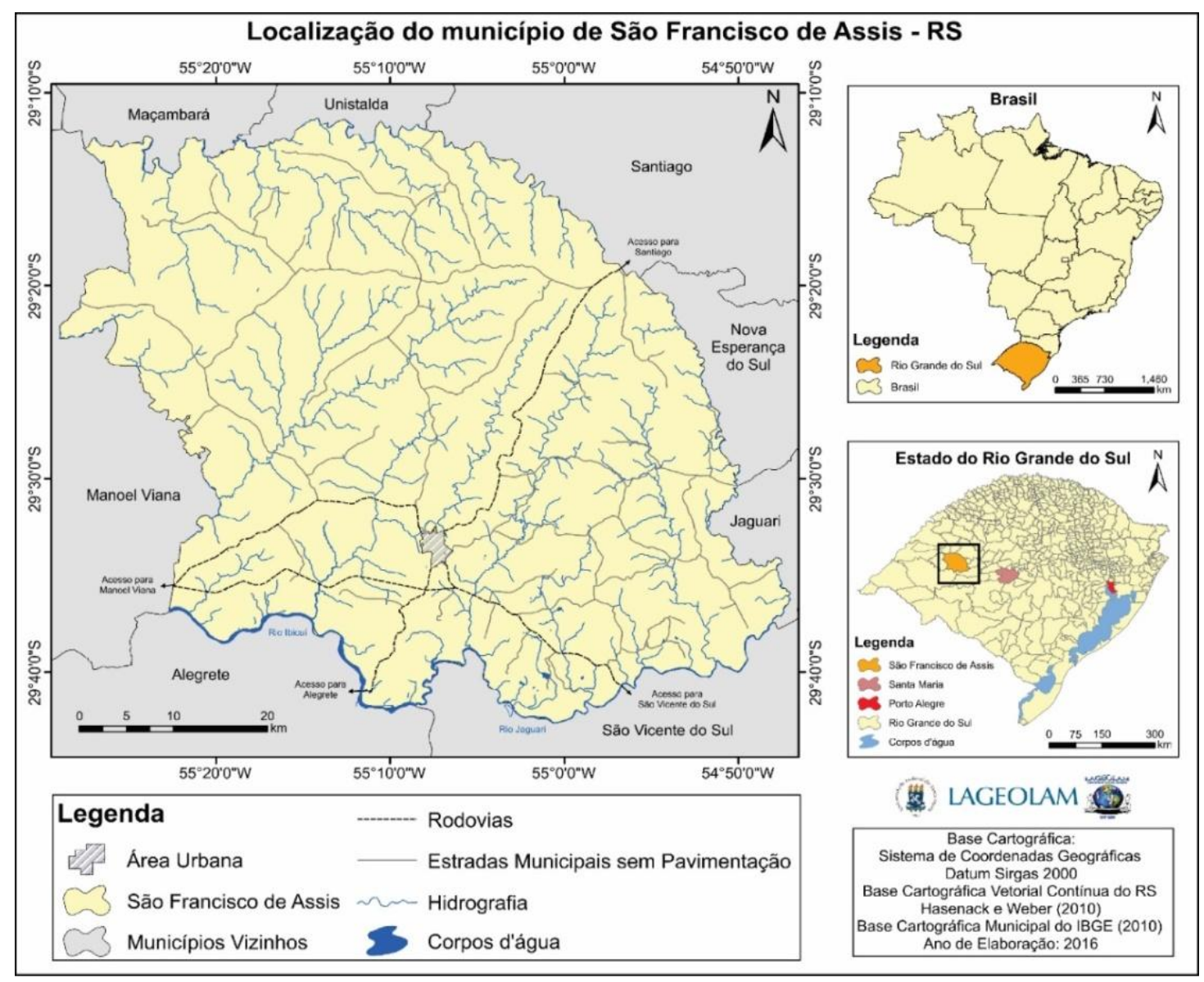

Figure 1: Localization map of the municipality of São Francisco de Assis / RS /Brazil 


\section{Physiographic Characterization of the Municipality of São Francisco de Assis}

The most characteristic landforms are hills with slopes between $5 \%$ and $15 \%$. There are more pronounced slopes, more than $15 \%$, in reliefs of buttes and mounts that constitute a busy belt in the center-north of the municipality that separates the highlands from the lowlands, characterized as the border of the plateau. In addition, there are high slopes in buttes e mounts testimonies dispersed in the relief of hills (ROBAINA \& TRENTIN, 2019).

According to several authors, an increase in soil loss occurs when surface slope is increased (LATTANZI et al., 1974; BRYAN, 1979; MOREIRA, 1992; SALOMÃO, 1999; AMORIM et al., 2001) associated with the greater impact angle of the rain drops on the surface of the soil and the greater ease with which the particles move in the direction of the slope by the effect of gravity.

In relation to the lithologies, in the municipality there is a thick fluvial-aeolian succession that begins with outcrops of the Sanga do Cabral Formation (LAVINA, 1988), represented by fine sandstone, pink or orange, with cross-laminated lamination and subordinately layers of red shale, with decimetrical thicknesses.

It follows, to the more abundant sedimentary sequences that appear in the municipality, the sedimentary rocks of origin of aqueous flows, classified by Scherer et al. (2002), as Guará Formation of Mesozoic age. These rocks are characterized by their sand texture with dispersed siliceous granules, sometimes well-defined structure of grooved and planar cross strata with short, medium and flat-parallel sets. The cementation of these blocks of sandstone consists of an iron oxide shell, which is very thin and as this protective layer is ruptured the substrate becomes friable and susceptible to surface dynamics processes.

The Botucatu Formation, superimposed, is formed by medium to fine sandstones, showing tangential cross stratification, from medium to large (SCHNEIDER et al., 1974). They appear in a narrow strip of the area near the Plateau Ridge and in intercalations with volcanic rocks.

Volcanic rocks cover the Paraná Basin in the Mesozoic (NARDY et al., 2002; WILDNER, et al. 2007) corresponding to dark gray, massive or vesicular basalts with intergranular arrangement and gray lithotypes with characteristic horizontal stratification, defined as rhyodacites. Recent deposits form the channel and overflow deposits of the rivers, which make up the study area.

Based on IBGE, (2002), the municipality of São Francisco de Assis the following classes of soils: Fluvic Neosols, Gleysols, Planosols, Lithic Neosols, Nitosols, Grayish Argisols, Red-yellow Argisols, Red Latosols and Quartzarenic Neosols.

The soils are associated to the different relief conditions and geological substrate present in the area of the municipality. Associated with the channel of the Ibicuí River, on the deposits of bars of meander occur soils of the type Fluvic Neosols and in the areas of flat of flood plain Gleysols and Planosols.

In areas with steep slopes, the soils are of the Lithic Neosols, which comprise shallow soils, where the thickness of the horizons on the rock generally does not exceed $50 \mathrm{~cm}$. In the center-north of the municipality, associated with basic volcanic rocks, they develop soils of the Nitosols type, clayey, structure in blocks strongly developed, with little differentiation of horizons. These soils were defined as low susceptibility to erosion, due to the binder set that gives a resistant structure.

The Grayish Argisols, occurring in the SE region of the municipality present grayish colors due to the drainage restriction and to the substrate of mudstone and fine sandstones in which they develop.

Associated with sequences of the sandstones of the Sanga do Cabral Formation, occur the Red-yellow Argisols (ferralsols) that present a clay accumulation horizon, B textural (Bt). They occur, also, to the northeast of the area of the municipality, on substratum of acidic volcanic rocks. Although they develop the characteristic horizons, they present little thickness, around $60 \mathrm{~cm}$. There is a predominance of the surface horizon A of the moderate and prominent type, mainly presenting the medium / clay texture.

Red Latosols that develop on sandstones of the Guará Formation represent the predominant soil of the municipality. They are well-drained, uniform texture and structure in depth, porous, of medium texture with high content of fine sand, which confers high erosive potential.

The soils with the greatest erosive potential are the Quartzarenic Neosols that develop over the Guará sandstones and are often associated with the Red Latosols, especially in a portion in the center of the municipality. 


\section{Methodological Procedures for the Mapping of Erosive Fragility}

The base maps for the definition of the map of erosive fragility were slope, soils, lithology and land use, with weights assigned to each of the variables present in the base maps. The maps were organized in information plans in the raster format with spatial resolution of 90 meters, since the database of the digital elevation model was the Shuttle Radar Topography Mission (SRTM) data.

From the topographic base, the map of slopes in percentages, with limits of 5\% and $15 \%$, was generated, being the limit of $5 \%$ related to the occurrence of the beginning of the relief denudation processes and the limit of $15 \%$ related to slope that can condition the occurrence of mass movements and associated with the maximum limit of employment of agricultural mechanization (IPT, 1981).

The land use map was generated by supervised classification with the "maximum likelihood" classifier in GIS, and the training and validation samples were identified in the fieldwork, and the satellite image used was the LANDSAT satellite image 8, March 2018 OLI sensor.

After the definition of the weights of each of the base map variables, they were reclassified through the reclassify tool in the ArcGIS GIS, where the weight of the variable was assigned to the pixel value (Figure 2).

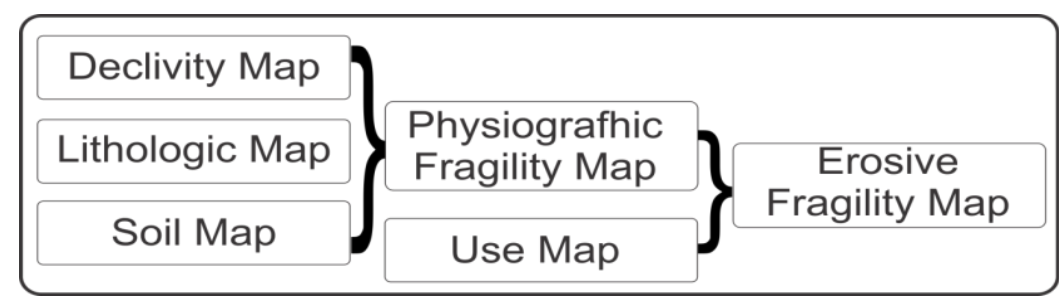

Figure 2: Flowchart orienting the procedures for the mapping of erosive fragility in the municipality of São Francisco de Assis / RS.

In terms of slope analysis, pixels with slopes less than 5\% received weight one (1), slopes of 5\% to $15 \%$ received weight two (2) and slopes greater than $15 \%$ received weight three (3).

The volcanic crystalline rocks are directly the least susceptible, followed by the Botucatu rocks, because they are affected by the volcanic rocks that give a greater cohesion. The sandstones with intercalations of fines and concretions of the sequence of the Sanga do Cabral Formation have a medium susceptibility and the friable sandstones of the Guará Formation have relatively higher susceptibility. Thus, the substrate of volcanic rocks received weight one (1), the sandstone substrates defined as Botucatu Formation weight two (2); the rocks of the Sanga do Cabral Formation and recent deposits received weight three (3); the sandstone substrates defined as Guará Formation were given weights four (4)

The soil associated with the classes of Gleisols, Lithotic Neosol, Fluvic Neosols and Planosols were given one (1); the types associated with the Red Nitosols and Bruno-Grayish Argisols, weight two (2); the Red Argisols were given three (3); the Red Latosols, weight four (4) and the types Quartzarenic Neosols received weight five (5).

For the use map, the areas occupied by water bodies received zero weight (0), the areas occupied by forests and riparian forests received weight one (1), the areas occupied by eucalyptus forestry received weight two (2); the areas occupied by the fields received weight three (3); the areas occupied by agriculture and Urban Area received weight four (4) and the areas occupied by exposed soils received weight five (5).

The mapping of erosive fragility was carried out by the map algebra operation carried out in the GIS, using the Raster Calculator tool. Two operations of sum of raster were carried out: in the first operation the sum of the weights referring to the Declivity, Lithology and Soils was defined, being generated the Physical Fragility; in the second operation the sum of the Physiographic Fragility and Land Use and Ocupation, and was defined as Erosive Fragility Map (Figure 3).

The fieldwork was carried out through the roads and paths that cross the municipality, identified by field points, describing the relief, use and occupation of the soil, identifying lithologies and soils. The observed erosive processes were recorded with photographs, located with positionally global equipment and described in relation to form and processes. The field points where erosive processes were identified was basis for the analysis of the mapping of the degrees of fragility defined in the crossing of the data. 


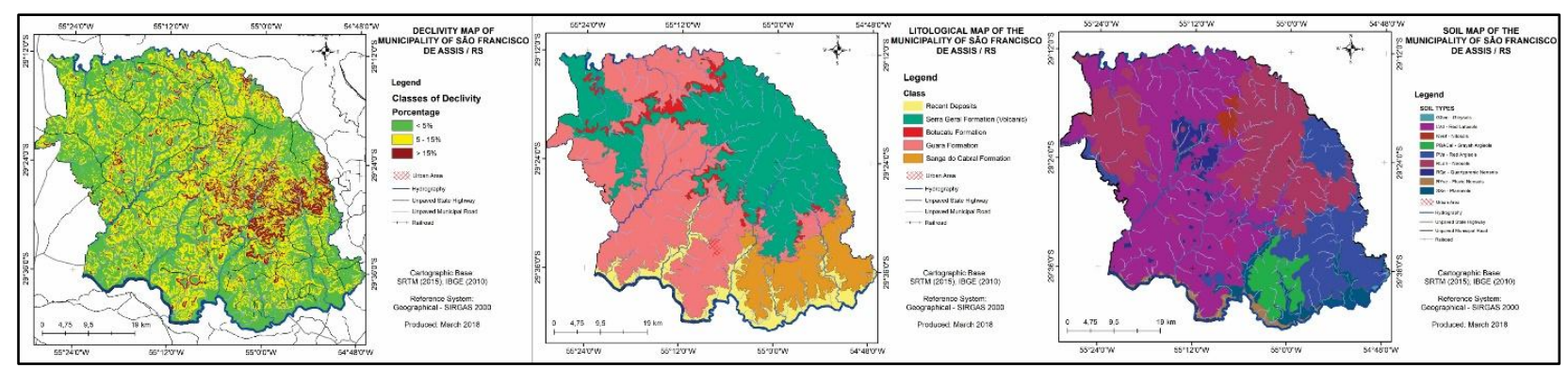

Figure 3: Slope maps, lithologies and soils used to obtain for the mapping of erosive fragility in the municipality of São Francisco de Assis / RS.

\section{Physiographic Parameters and Susceptibility to Erosive Processes}

Crossing the parameters that define the composition of the slope (rock / soil) with inclination conditions (declivity) determined the areas of erosive fragility (Figure 4).

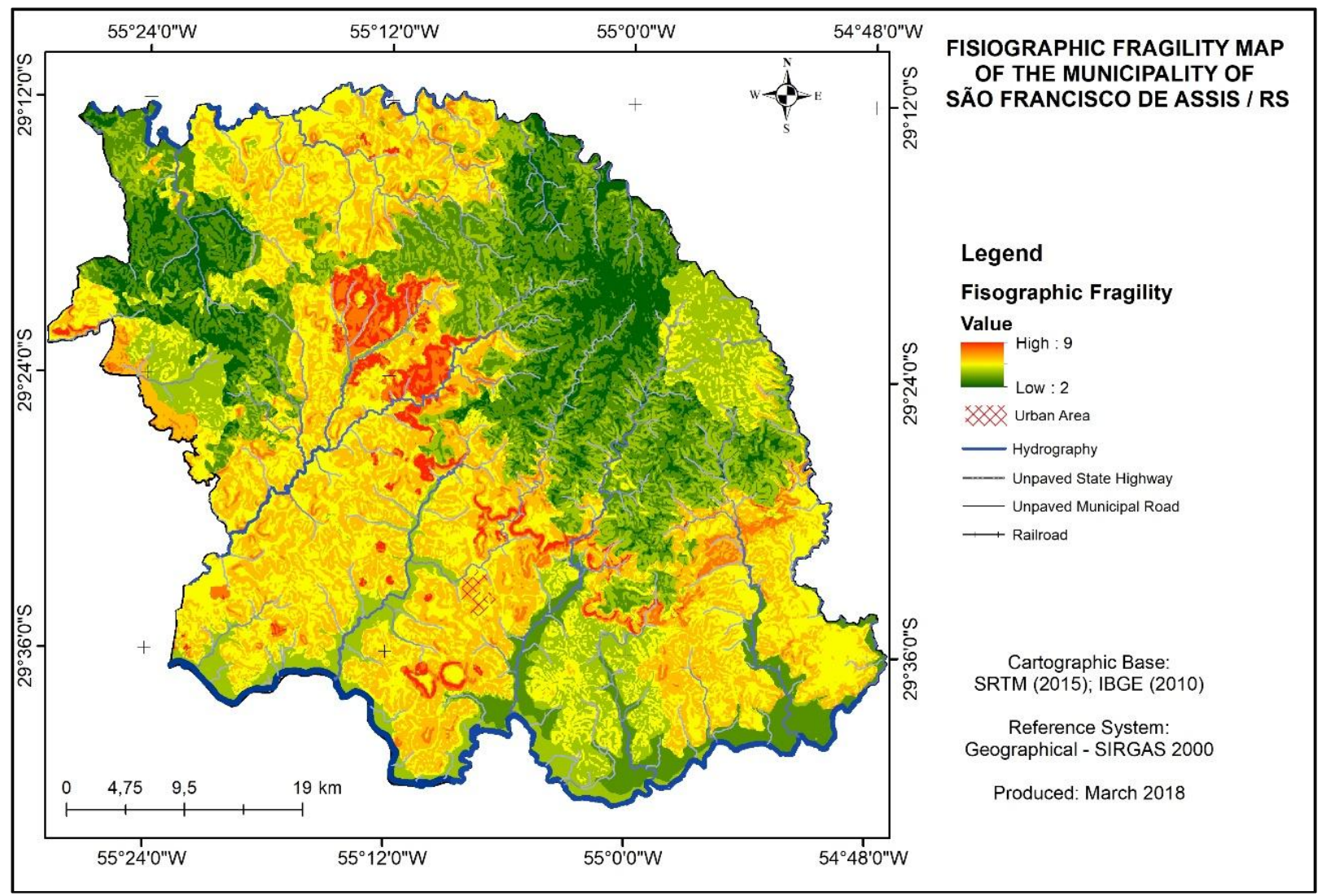

Figure 04: Map of erosive fragility by Physiographic parameters of São Francisco de Assis / RS.

The areas of very low physiographic fragility make up $19 \%$ of the total and are located NE and NW of the area of the municipality, where there is a relief of soft hills composed of volcanic rocks and shallow soils.

Occupying $23 \%$ of the total of the municipality, the areas of low physiographic fragility occur associated with areas of very low fragility, but marking more inclined portions of relief.

The areas with medium erosive physiographic fragility represent $20 \%$ of the total. They are located in a large area to the SE of the municipality associated with hills of thin sandstones with layers relatively more cohesive that limit the erosive processes.

The areas of high physiographic fragility occur in a large central area of the municipality associated with sandstones with sandy and thick soils, in hills relief, constituting $35 \%$ of the total.

In the more inclined portions associated with the edges of mounts and buttes of sandstones occur an area with very high physiographic fragility, making up 3\% of the total area of the municipality. 


\section{Erosive fragility the Municipality of São Francisco de Assis}

The land use and occupation defined five units of analysis: forests of slopes and ciliary, silviculture, agricultural areas, exposed soil and fields (Figure 5). The forests of slopes and ciliary are characterized mainly by the presence of concentrations of native vegetal species of tree-shrub size. They occur along the main rivers and on steep slopes in the area of the ridge of the plateau. The silviculture is characterized by large extensions of planted areas, sites used for the cultivation of exotic tree plant species, mainly eucalyptus (Eucalyptus sp.).

The crops are characterized by a predominance of temporary monocultures such as soybean, corn and rice. They are located mainly in the north, east and west portions of the municipality with a coverage of about $22.6 \%$ of its territorial area. Associated to cropping areas, occur in areas where soils are exposed and on sandy fields. The sites with exposed soil are mainly in the northeastern, central and southwest areas of the municipality with territorial coverage. Fields and pastures are characterized by the predominance of large areas with planted and native grasses. They are distributed mainly in the northeast, northwest and centersouth portions of the municipality, covering about $46.5 \%$ of its territorial area.

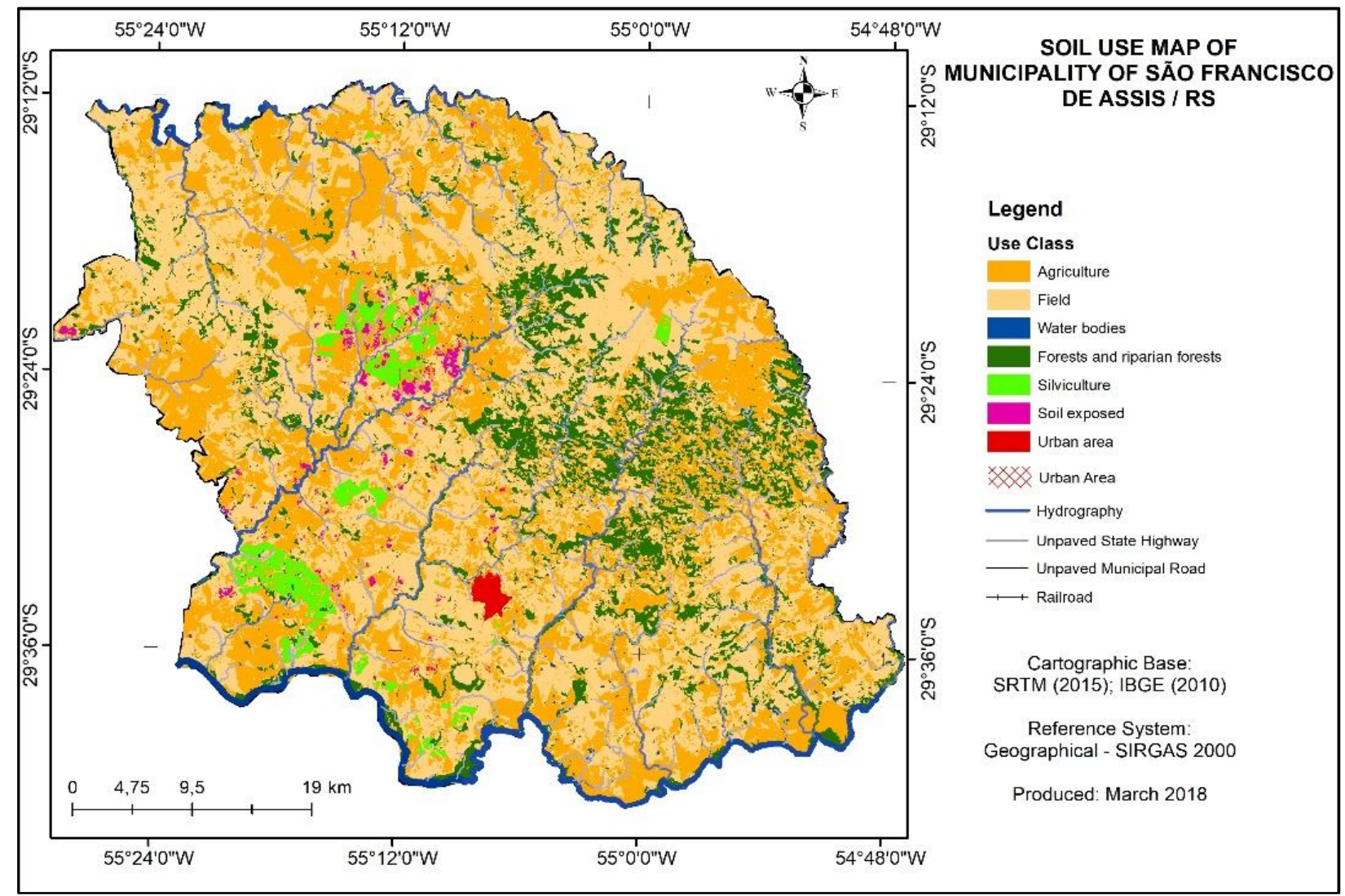

Figure 5: Map of land use and occupation of São Francisco de Assis / RS.

Erosive fragility is a relation between the physiographic conditions, defined by the relief attributes, lithologies and soils, and information of land use and occupation (Figure 6).

The areas with the lowest erosive fragility, occur in the NW portion of the municipality, and are related to the occurrence of natural tree vegetation. Situations of greater possibility of development of the erosion process are very localized and restricted to areas where small properties develop crops such as corn, tobacco and sugarcane.

The low erosive fragility corresponds to the areas of shallow and clay soils, developed in volcanic rocks occupied by native pasture with use of cattle breeding.

In the municipality, areas with medium erosive fragility occur at the extreme NE-E and NW, formed by soils on volcanic rocks or sandstone with volcanic contribution where the predominant uses agricultural. In the extreme SE of the municipality on substrate of sandstone with clayey matrix and cohesive layers due to cementation, and intense agricultural use. 


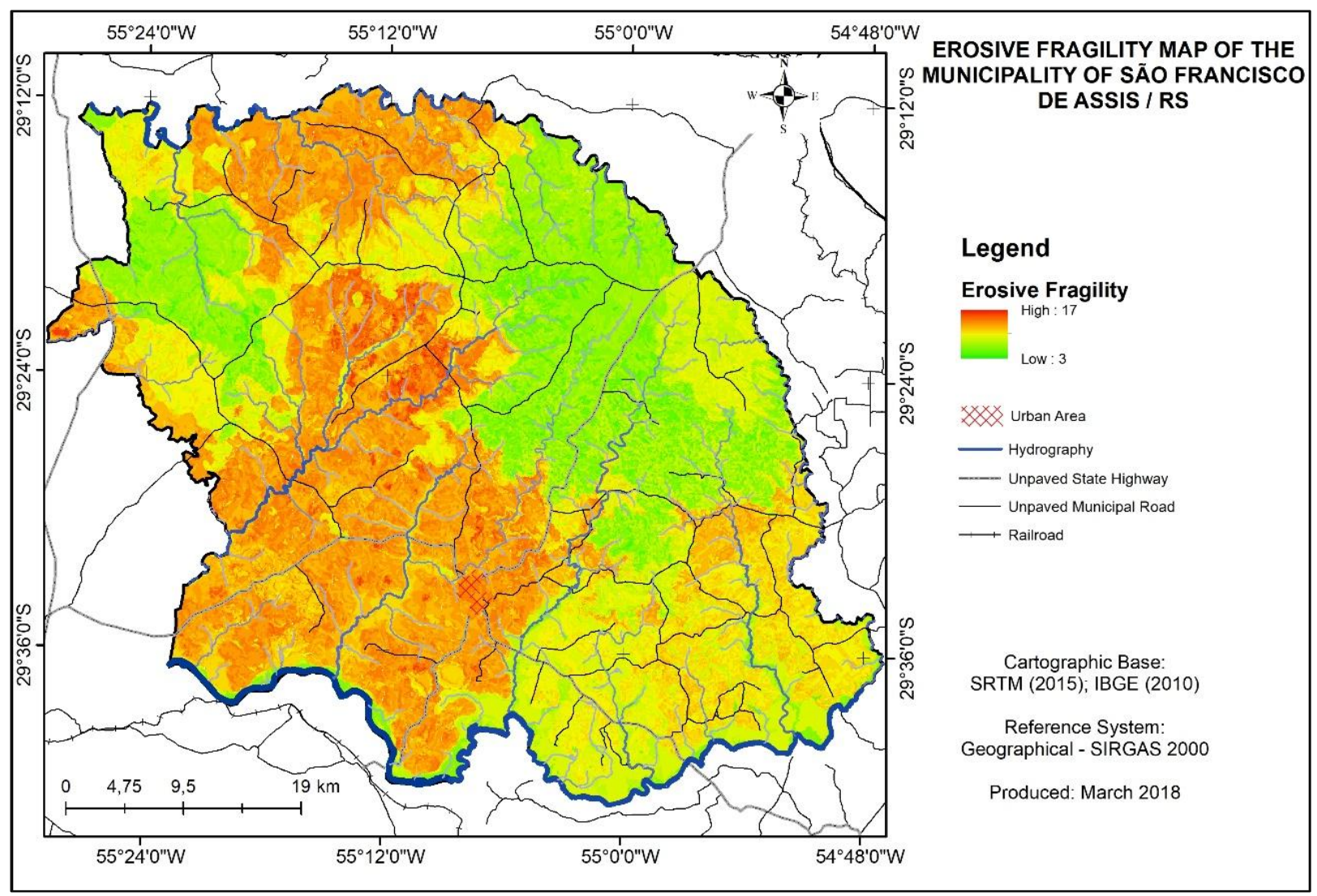

Figure 6: Map of Erosive Fragility of São Francisco de Assis / RS.

Associated with the substrate of sandstones with very fragile soils, which make up the central portion of the municipality, conditions of medium erosive fragility are given by the presence of use forestry, with vegetation at an advanced stage of development. Conditions of medium erosive fragilities also occur where the native pasture is maintained and the use is cattle breeding.

The areas of high erosive fragility are associated with agricultural use in sandstones with sandy soils. The occurrence of very high erosive fragility is associated with the substrate of sandstones, friable soils and low soil cover. Also associated with the rocky base of buttes end mounts, in contact with friable soils, forming ravines and gullies.

\section{Field Analysis of Erosive Fragility}

For the analysis of the erosive fragility defined by the intersection of information, field surveys were performed.

The first area of analysis, next to the field point 04, is shown in Figure 7. It is located on a sandstone substrate of the Guará formation, relief of hills with cornices and buttes of more resistant sandstone and land use as a native pasture. There are linear erosive processes at the base of the cornice in the north, where conditions varying from medium to high susceptibility are indicated.

The second area, next to the point 05 of field (Figure 8) occurs in relief of hills with elevation of 148 meters. In the northern portion, the representation was more varied due to the difference in the vegetal cover. To the south, linear erosions occur at the base of the buttes, indicated as areas of high susceptibility in cartography.

In the third area of comparison (Figure 9), field point 09, occurs in a hill, associated with sand field (Figure 9-a) and gully development (Figure 9-b). The map of erosive fragility identifies very clearly the area with sandy development, but the gully process was not well represented, probably because the generation has a strong control of the inadequate use of the contour system, interrupted in the contact between the properties. 


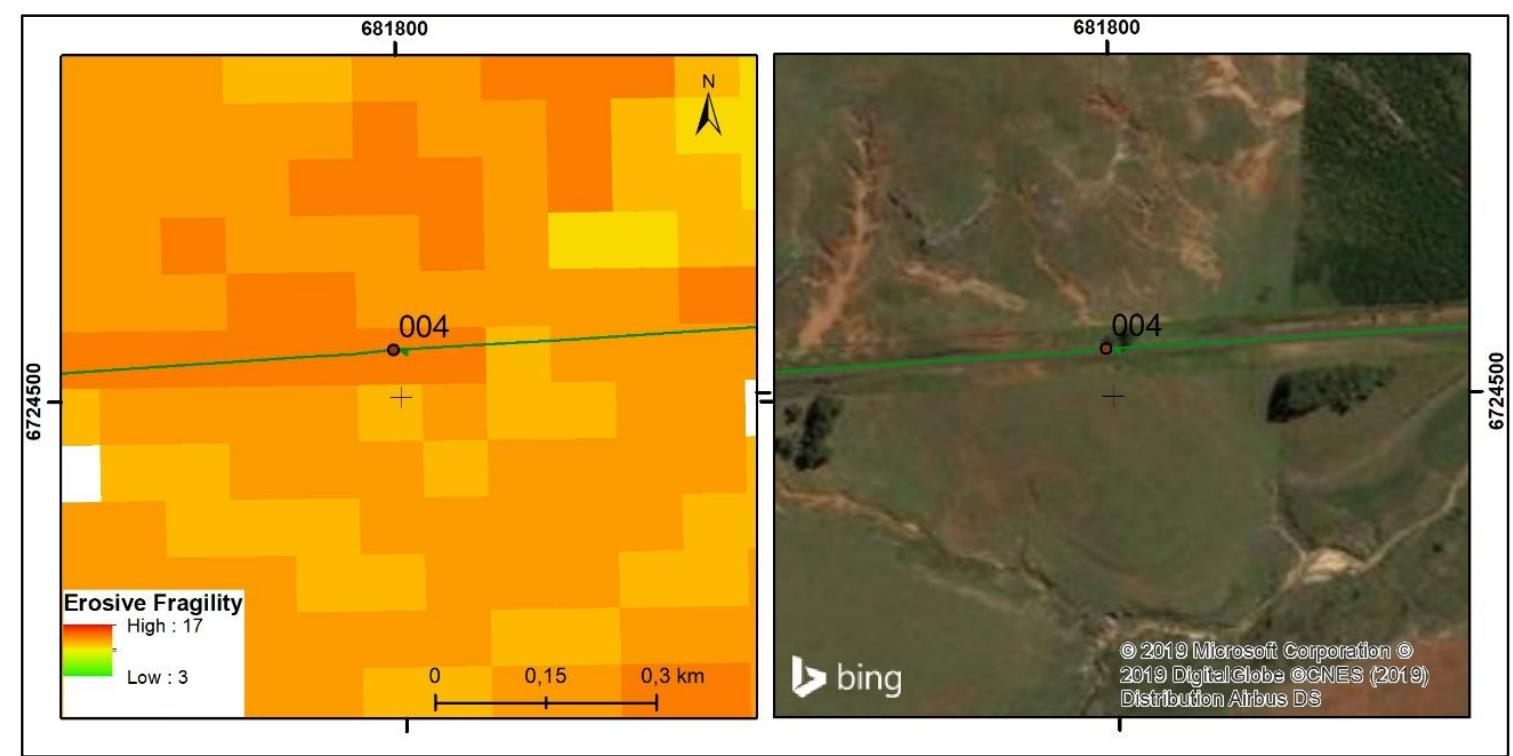

Figure 7: Area associated with field point $04-$ sept/2018.

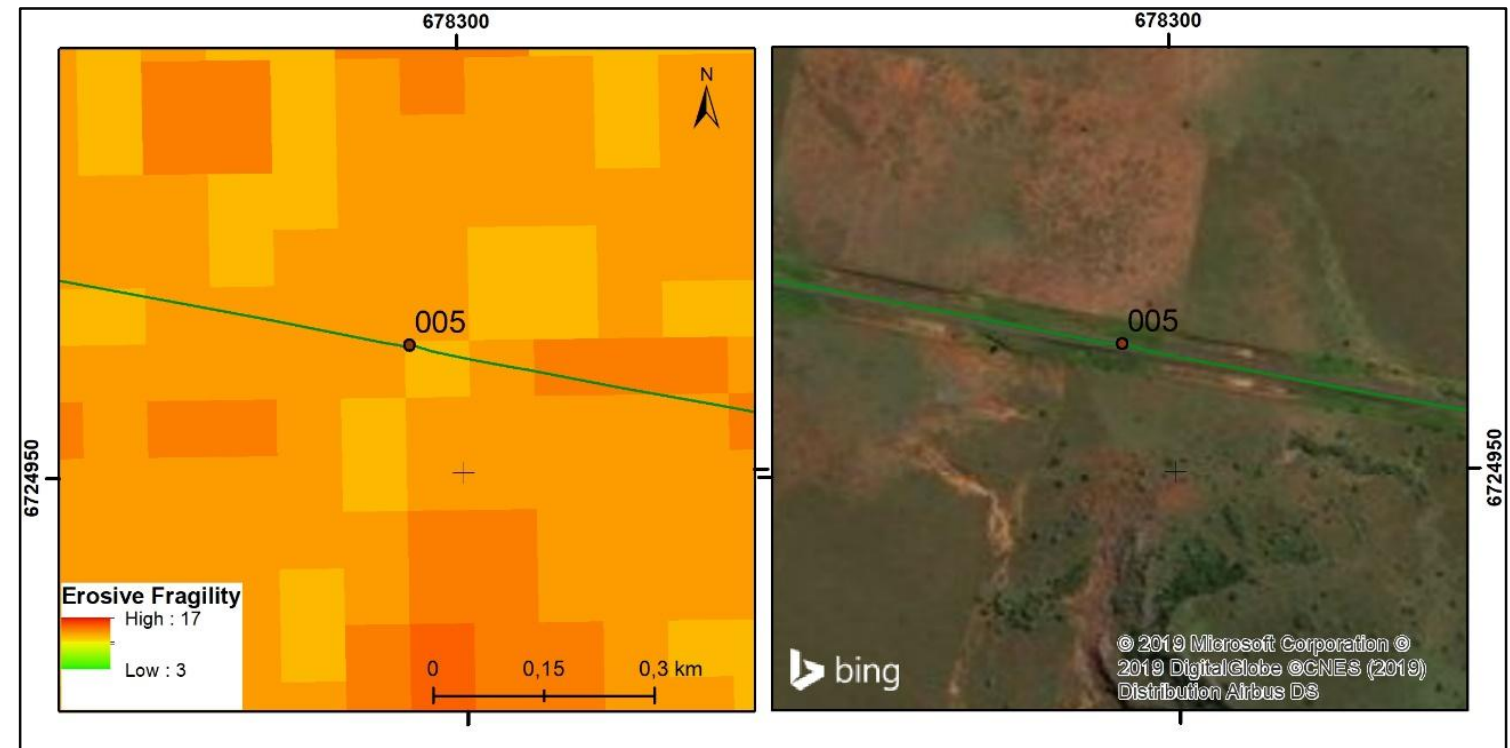

Figure 8: Area associated with field point 05 - sept/2018.

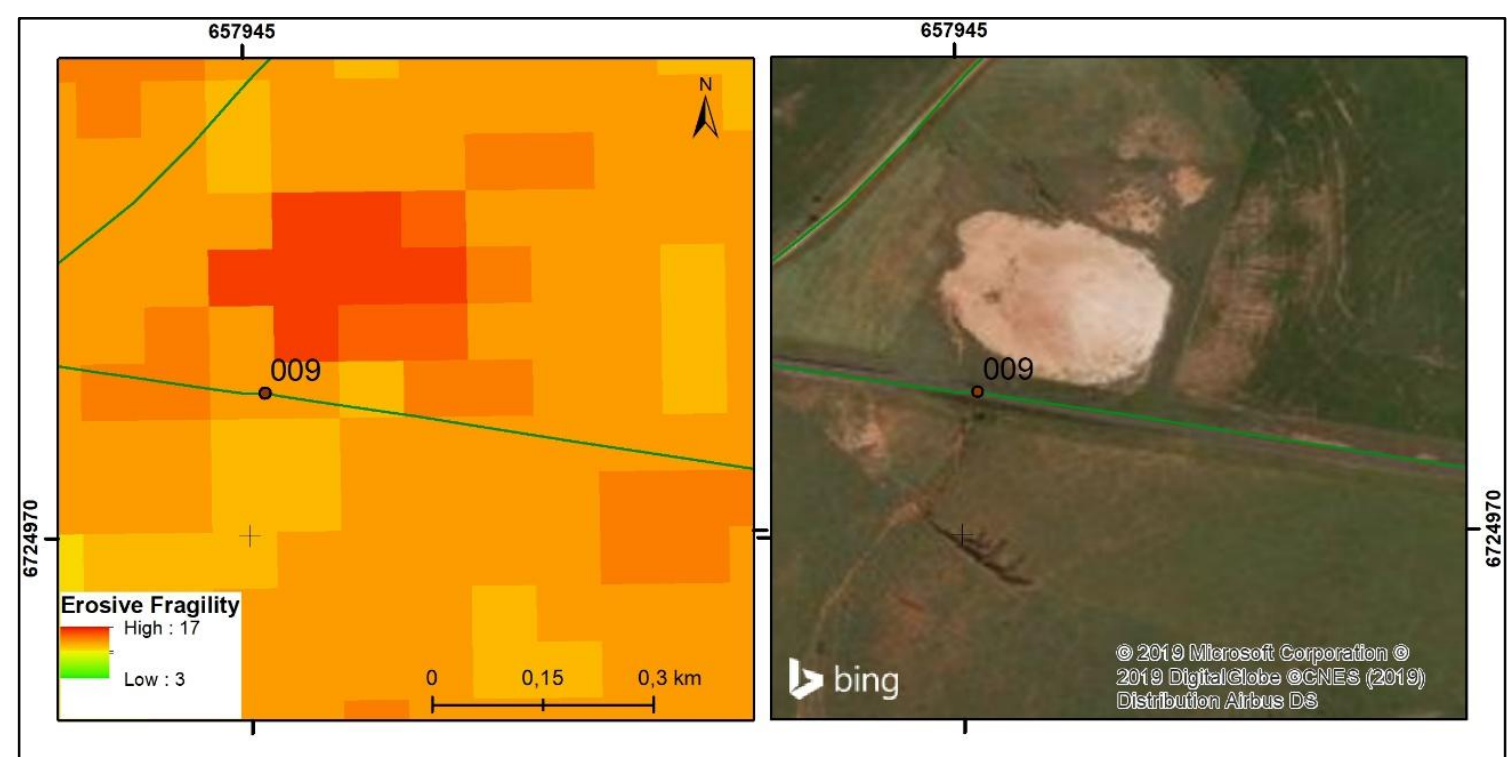

Figure 9: Area associated with field point $09-$ sept/2018. 

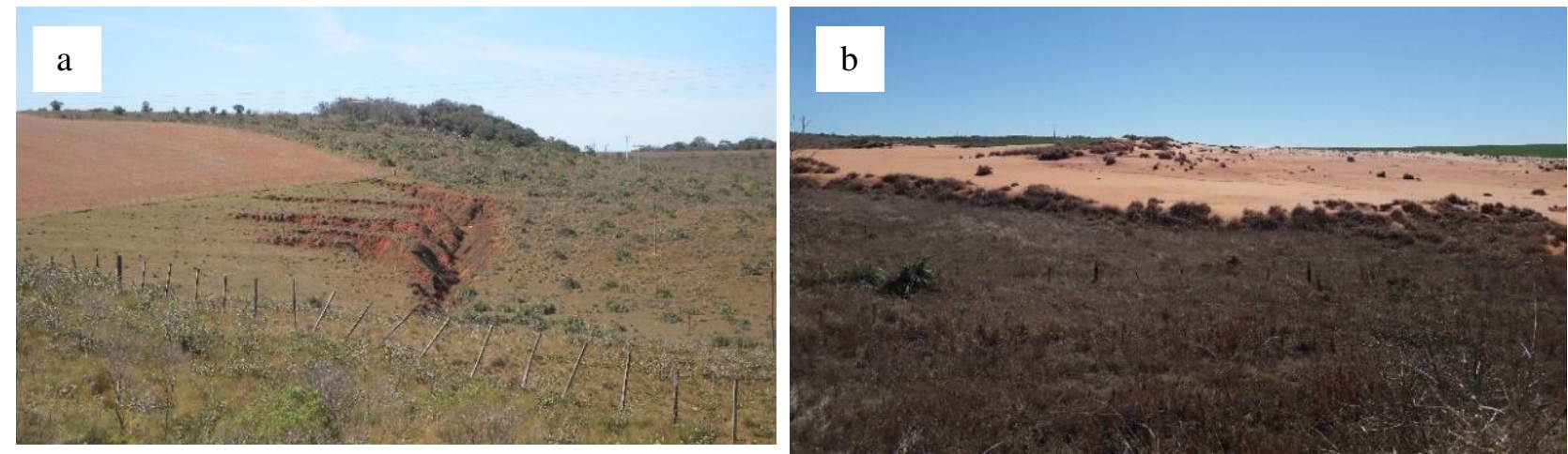

Figure 9: a) The gullies in the contact of the plantations with native pasture; b) sand spots in the native pasture. sept/2018.

In the fourth area of comparison, field point 16, (Figure10) we observe the occurrence of gullies in a step east-southeast, which the cartography indicated high susceptibility in the upstream and very high portion downstream of the gully (Figure 10a). Where more bushy and arboreal vegetation occurs, the conditions are of medium susceptibility.

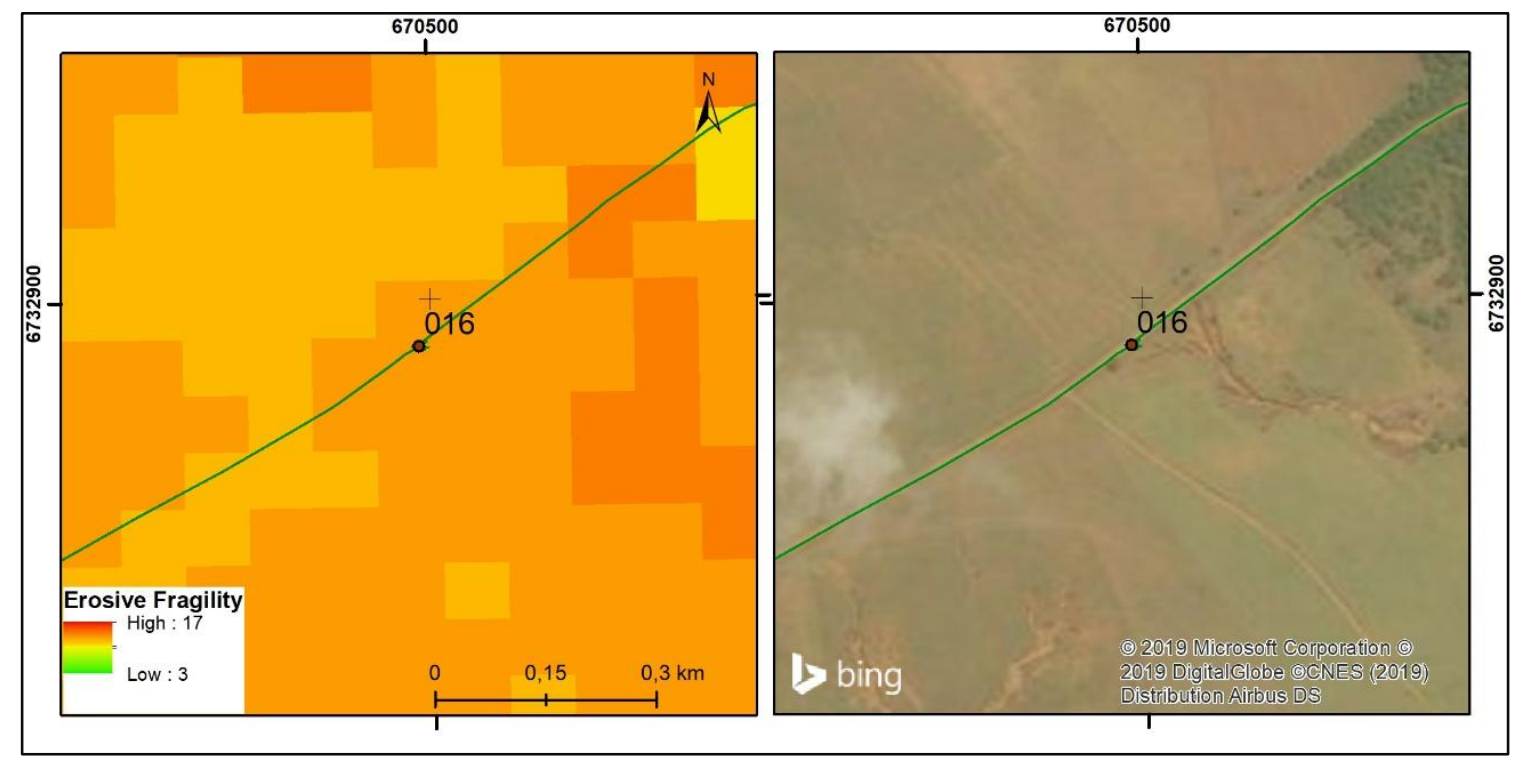

Figure 10: Area associated with field point $16-$ sept/2018.

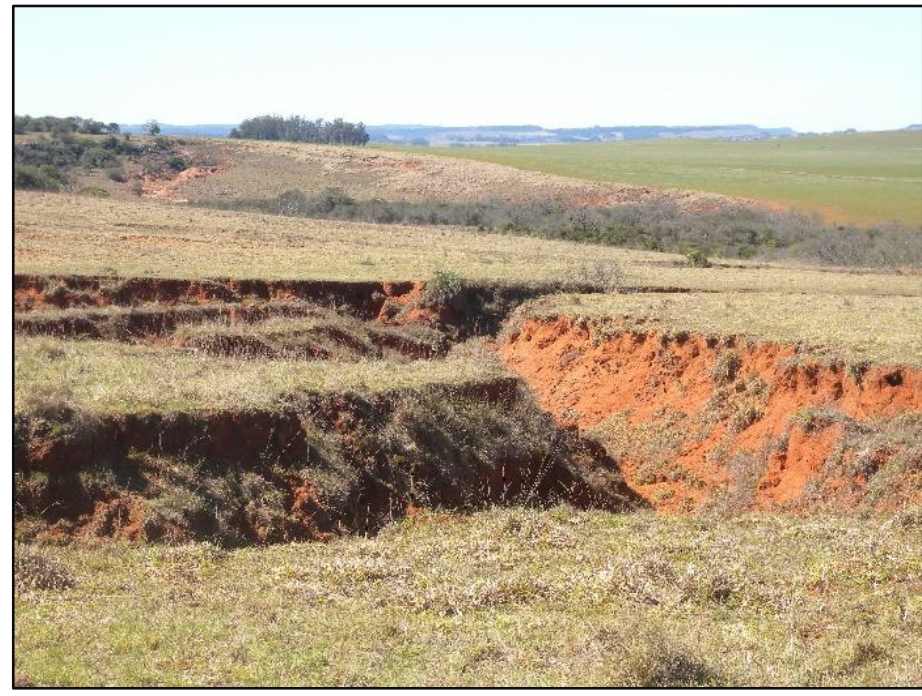

Figure 10a: Shallow cut areas of eucalyptus plantations. - sept/2018

The sixth area in point 19 (Figure 11), on a hill where it occurs east of the point, a sand field (Figure 11a), very well defined in the map of erosive fragility. The areas with soils covered with native pasture 
susceptibilities were determined as medium susceptibility. The gully that develops south of the field point is represented in the map of fragility by conditions of high susceptibility.

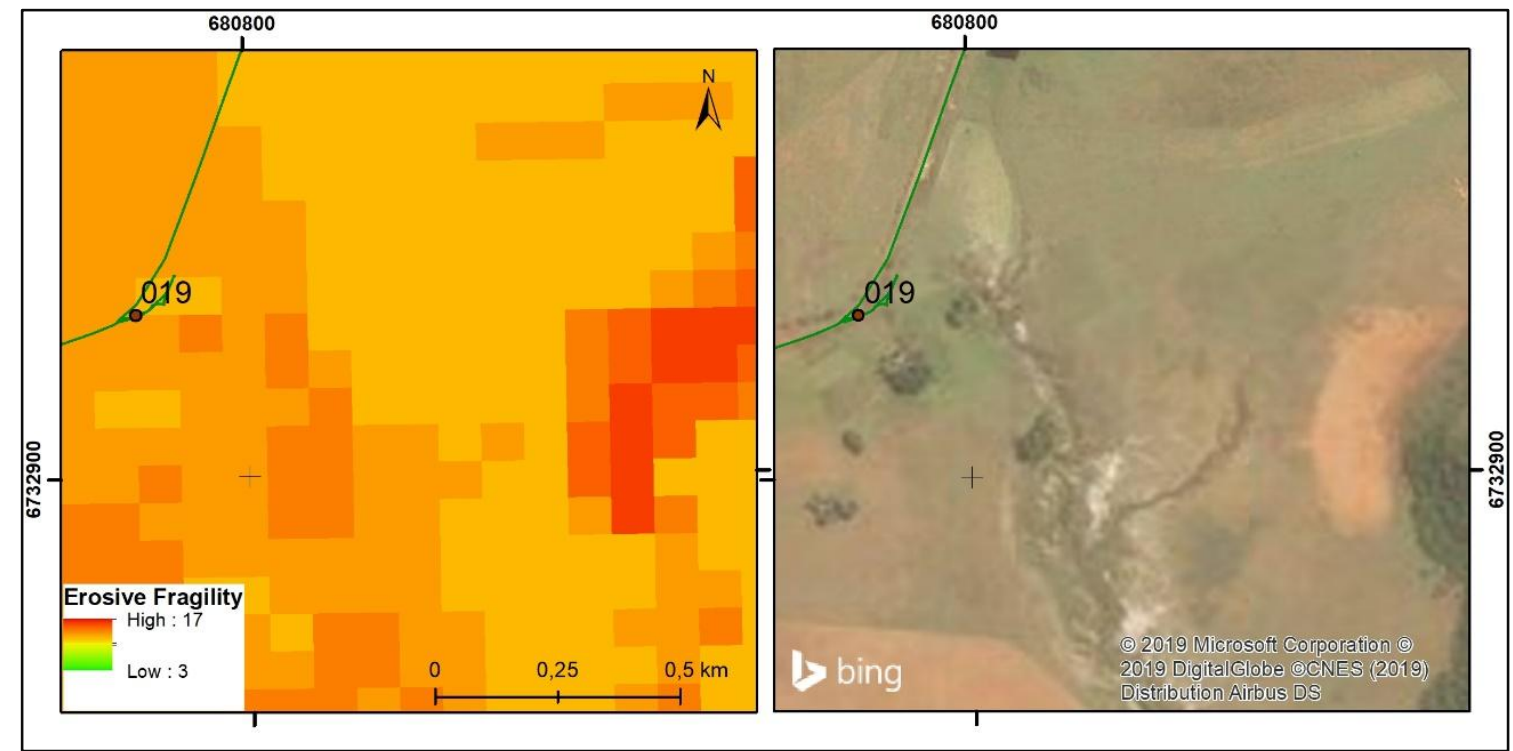

Figure 11. Area associated with field point $19-$ sept/2018.

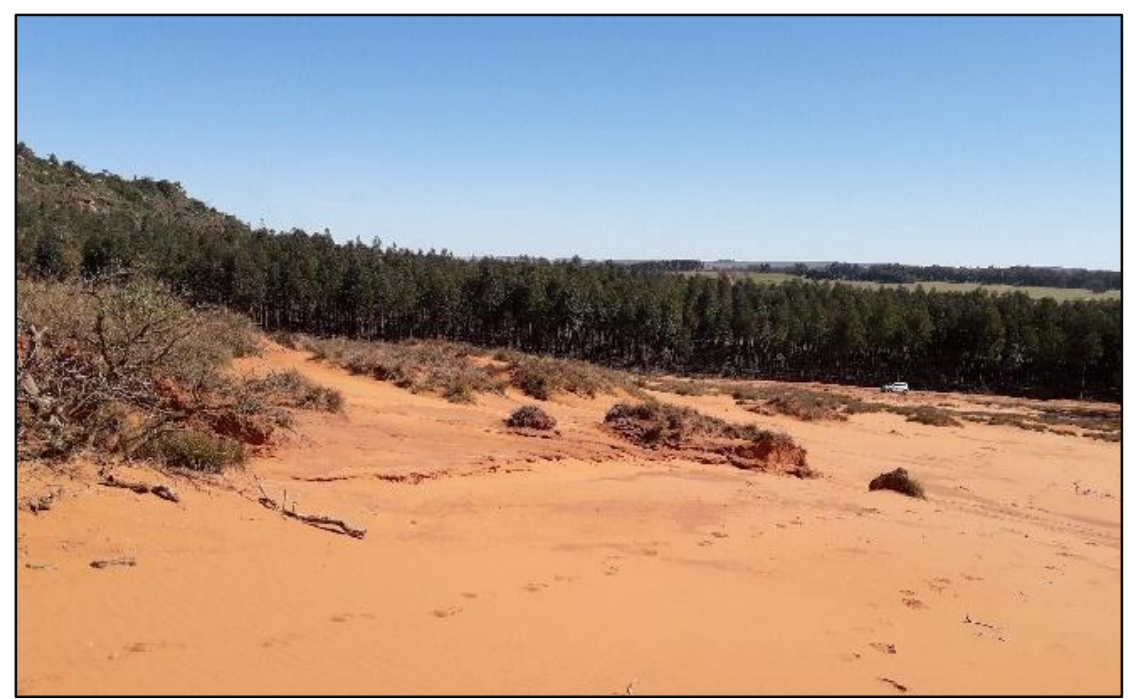

Figure 11a: Area with a sand field. sept/2018

\section{Final Considerations}

The systemic analysis of the variables chosen for the study, together with the multi-criteria methodology applied through GIS, allows the final product of this research to indicate how the environment behaves, allowing interpretations of the most different knowledge areas.

Thus, the work showed the importance of the multi-criteria relationship involving physical attributes of the landscape and the study of land use is essential in studies of fragility and environmental potential. In addition, this crossover enables diagnostics of automated environmental impacts when combined with GIS technology.

The areas of high physiographic fragility occur in a large central area of the municipality associated with sandstones with sandy and thick soils, in hills relief, with agricultural use and low soil cover, constituting $35 \%$ of the total.

The fieldwork allowed verifying a good representation of the erosive fragility in the proposed mapping, demonstrating effectiveness in the definition of the weights of the variables used.

This same methodology should be used in other areas to verify the response of the mapping and the validation of the variables used. 


\section{References}

AMORIM, R. S. S.; SILVA D. D; PRUSKI, F. F. \& MATOS, A. T. Influência da declividade do solo e da energia cinética de chuvas simuladas no processo de erosão entre sulcos. Revista Brasileira de Engenharia Agrícola e Ambiental. v.5, n.1, p.124-130. Campina Grande, 2001.

BACELLAR L. A. P. Condicionantes geológicos, geomorfológicos e geotécnicos dos mecanismos de voçorocamento na bacia do rio Maracujá. 226p. Tese de doutorado. (Pós-Graduação e Pesquisa de Engenharia), Instituto Alberto Luiz Coimbra de Pós-Graduação e Pesquisa de Engenharia, da Universidade Federal do Rio de Janeiro, Rio de Janeiro, 2000.

BIGAREllA, J. J.; BECKER, R.D.; PASSOS, E. Estrutura e Origem da Paisagens Tropicais e Subtropicais. Ed. UFSC. v. 2, 1996. 875 p.

BRYAN, R. B. The influence of slope angle on soil entrainment by sheetwash and rainsplash. Earth Surface Process. BSG. v.4, n.1, p.43-58, 1979.

CALDERANO FILHO, B.; BERING, S. B.; CALDERANO, S. B.; GUERRA, A. J. T. Suscetibilidade dos Solos à Erosão na Microbacia do córrego Fonseca, Região Serrana do Estado do Rio de Janeiro. Anais... Simpósio Regional de Geoprocessamento e Sensoriamento Remoto - GEONORDESTE 2014. Aracaju, Brasil, 18-21 novembro 2014.

CANEPPELE, J. C. G.. Espacialização da arenização a partir da Ecodinâmica e da Cartografia Ambiental. 129p. Dissertação. (Pós-Graduação em Geografia e Geociências), Universidade Federal do Rio Grande do Sul, Porto Alegre, 2017.

DOMINGUES, E. N.; M. ROSSI, M.; MATTOS I. F. A.; ABE, K. \& KITADA, M. Tipologia e Distribuição dos Processos Erosivos na Microbacia do Ribeirão Água da Cachoeira, em Paraguaçu Paulista, SP. Revista Brasileira Ciência do Solo, 22:141-149, 1998.

FUJIMOTO, N.S.V.M.; GONÇALVES, F.S.; ZANCANARO, C. Caracterização das Formas de Relevo em Degraus de Abatimento nos Municípios de Manoel Viana e São Francisco de Assis, Região Sudoeste do Estado do Rio Grande do Sul. Revista Brasileira de Geomorfologia, n. 11, p.69-74, 2010.

INSTITUTO BRASILEIRO DE GEOGRAFIA E ESTATÍSTICA (IBGE). Ministério do Planejamento, Orçamento e Gestão. Pedologia: Mapa Exploratório de Solos do Estado do Rio Grande do Sul. Rio de Janeiro: IBGE, 2002.

INSTITUTO BRASILEIRO DE GEOGRAFIA E ESTATÍSTICA (IBGE). Censo 2010. Disponível me: < https://censo2010.ibge.gov.br/sinopse/index.php?uf=43\&dados=1 >. Acesso em: 22 abr. 2018.

INSTITUTO BRASILEIRO DE GEOGRAFIA E ESTATÍSTICA (IBGE). Cidades: São Francisco de Assis. Disponível em: < https://cidades.ibge.gov.br/brasil/rs/saofrancisco-de-assis/panorama >. Acesso em: 17 abr. 2018.

IPT, I. de P. T. do E. de S. P. Mapa geomorfológico do Estado de São Paulo. Escala 1:500.000. . São Paulo: IPT Publicação 1183. , 1981

LATTANZI, A.R.; MEYER, L.D.; BAUMGARDNER, M.F. Influences of mulch rate and slope steepness on interrill erosion. Soil Science Society of America. Journal, Madison, v. 38, p.946-950, 1974.

LAVINA, Ernesto Luiz Correa. The Passa Dois Group. In: 7 International Gondwana Symposium. São Paulo: Instituto de Geociências, p. 24-30. 1988.

MOREIRA C. V. R. Fatores condicionantes das voçorocas na sub-bacia do rio Santo Antônio, Bacia do rio Grande, MG. Belo Horizonte: IG/UFMG. 1992. 163p.

NARDY, A.J.R., OLIVEIRA, M.A.F., BETANCOURT, R.H.S., VERDUGO, D.R.H., MACHADO, F.B. Geologia e Estratigrafia da Formação Serra Geral. Revista Geociências, v.21, n.2, p.15-32, 2002.

ROBAINA, L. E. S.; TRENTIN, R. Estudos e zoneamento geoambiental do município de São Francisco de Assis - Oeste do Rio Grande do Sul. Revista de Geografia e Ordenamento do Território. p.323-344, 2019.

ROBAINA, Luís; TRENTIN, Romario (2019). Estudos e zoneamento geoambiental do município de São Francisco de Assis - Oeste do Rio Grande do Sul. Revista de Geografia e Ordenamento do Território (GOT), n. ${ }^{\circ} 16$ (março). p. 323-344, dx.doi.org/10.17127/got/2019. 
SALOMÃO, F. X. T. Controle e prevenção dos processos erosivos. In: GUERRA, A.J.T.; SILVA, A.S.; BOTELHO, R.G. (orgs.). Erosão e conservação dos solos: conceitos, temas e aplicações. Rio de Janeiro: Bertrand Brasil, 1999.

SCHNEIDER, R. L.; MÜHLMANN, H.; TOMMASI, E.; MEDEIROS, R. A.; DAEMON, R. F.; NOGUEIRA, A. A.Revisão estratigráfica da Bacia do Paraná. In: CONGRESSO BRASILEIRO DE GEOLOGIA, 28., 1974, Porto Alegre. Anais do... São Paulo: Sociedade Brasileira de Geologia, 1974. v. 1, p. 41-65.

SCHERER, C. M. S.; FACCINI, U. F.; LAVINA, E. Arcabouço Estratigráfico do Mesozóico da Bacia do Paraná. In: HOLZ, M. e DE ROS, L.V. Geologia do Rio Grande do Sul. Porto Alegre: CIGO/UFRGS, p. $335-354,2002$.

SILVA, G. G.; OLIVEIRA, L. N. Análise da suscetibilidade e potencial à erosão laminar no município de São Miguel do Araguaia/GO. In: SIMPÓSIO BRASILEIRO DE SENSORIAMENTO REMOTO, 17. (SBSR), 2015, João Pessoa. Anais... São José dos Campos: INPE, 2015. p. 6511-6518.

VALladARES, G. S.; GOMES, A. S.; TORRESAN, F. E.; RODRIGUES, C. A. G.; GREGO, C. R. Modelo multicritério aditivo na geração de mapas de suscetibilidade à erosão em área rural. Pesquisa Agropecuária Brasileira, Brasília, DF, v. 47, n. 9, p. 1376-1383, 2012.

VIEIRA, C.L. \& VERDUM, R. Arenização e Erosão Hídrica no Sudoeste do Rio Grande do Sul: Análise dos Agentes Condicionantes e Considerações Básicas para Intervenções Mecânico-Vegetativas. Revista de Geografia (UFPE) v. 32, n. 1, 2015.

WILDNER, Wilson, HARTMANN, L. A. \& LOPES, R. C. Serra Geral Magmatism in the Paraná Basin a new stratigraphic proposal, chemical stratigraphy and geological structures. In: I WORKSHOP PROBLEMS IN THE WESTERN GONDWANA GEOLOGY. Gramado, v.1, p. 189-197, 2007. 